\title{
風洞実験によるかわらの振動と飛散現象の研究*
}

\author{
難 波 礼 治*1, 岡 本 覚*2, 芝尾金 男*3 \\ 佐 藤 正 美*3, 芝尾宜 秀*3
}

\section{Researches on Vibration and Scattering of Roof Tiles by Wind Tunnel Test}

\author{
Reiji NANBA, Satoru OKAMOTO*4, Kaneo SHIBAO, \\ Masami SATOU and Yoshihide SHIBAO \\ ${ }^{* 4}$ Interdisciplinary Faculty of Science and Engineering, Shimane University, \\ 1060 Nishikawatsu, Matsue-shi, Shimane, 690-8504 Japan
}

\begin{abstract}
A series of wind tunnel tests was conducted on the vibration and scattering behavior of full-sized model of roof tiles, which were used widely for roofings of Japanese wooden dwellings. This study has investigated the nature and source of the vibrating and scattering behavior of roof tiles with the aim of providing a better insight to the mechanism. The roof tiles were set up on the pitched roof in the downstream of the flow from the wind tunnel. The vibration of the roof tiles was measured by the Laser Doppler Vibrometry and the accelerometer, and the practical natural frequency of the roof tiles was analyzed by the method of impulse force hammer test. The motions of the vibration and scattering were observed by the high-speed video camera. Based on the consideration on the results of the measurements, there is a basic mechanism which can lead to flow-induced vibrations of the roof tiles. This mechanism is that of the so-called fluttering instability, which appears as the self-excited oscillation in the natural mode of the structure at the certain critical flow speed. It is concluded that the values of frequencies of the forced vibration for the fluttering coincide nearly with the values of natural frequencies.
\end{abstract}

Key Words: Wind Tunnel Test, Flow Induced Vibration, Flow Measurements, Roof Tiles, Vibration and Scattering

\section{1.}

本研究は, 古くから日本家屋の屋根莫き材として 広く用いられてきたかわらに関する研究で, 耐風性に 優れたかわらの開発や施工方法の確立を目指している.

強風によるかわらの被害は，台風等で少なからず 報告されており, 平成 11 年の建築基隻法の改正によ り台風等の強風によるかわらの脱落防止が従来にも増 して嵈しく規制されるようになってきた. かわらの飛 散に関する既往の研究では，縮尺した模型瓦を用いて 行われた実験が大部分である．例えば，かわらの表面 圧力の分布計測とかわらの浮き上がりに関する検討か ら，マク口的に観て飛散に至る限界流速等がある程度 明らかとなっている ${ }^{(1)}$-3). しかしながら，各々のか わらが飛散に至る詳細なメカニズム，すなわちミクロ な運動機構は依然として不明であり，かわらに作用す る風力特性については十分解明されてはいない，その 結果，而風性能を著しく向上させたかわら形状の設計 や施工方法には結び付いていないのが現状である.

* 原稿受付 2004 年 10 月 13 日.

*1 正員, 島根大学大学院( $3690-8504$ 松江市西川津町 1060).

*2 正員, 島根大学総合理工学部.

*3 (株)シバオ.

E-mail : okamoto@ cis.shimane-u.ac.jp
本研究では，かわらが風の影響を受けて飛散する 前兆現象である瓦の動摇(がたつき、ずれ)に着目し， それらの原因を探求して有効な対策に反映させること を目的としている．文献調查等によって，この “動 摇”が, 風の流れに起因して起こる “流体関連振動” の一種であることがわかっている ${ }^{(1)}$-(3). そこで害際 の台風の風速に相当する最大風速約 $50 \mathrm{~m} / \mathrm{s}$ の風洞実験 装置と実物かわらを用いて実験を行った. 使用した計 測機器は, 加速度センサ, FFT アナライザ, レーザ ドップラ振動計である. 風洞実験の他に, かわらの固 有振動数をインパルスハンマを使用したハンマリング 試験により測定した. 一方, 振動およひ飛散の詳細な 現象を高速度ビデオカメラで撮影した．また，熱線流 速計を使用し，かわら近傍の流れの計測を行った. そ の結果，かわらが振動し，飛散に至るまでの一連のメ カニズムがある程度明らかとなった.

\section{2.おもな眍 号}
$\theta:$ 屋根勾配
$\phi:$ 風向角
$U:$ 風速 $\mathrm{m} / \mathrm{s}$
$X:$ かわら表面に沿う主流方向の座標軸
$Y$ : かわら表面に沿う主流と直角の方向の座標軸
$Z:$ かわらの表面に垂直な方向の座標軸 


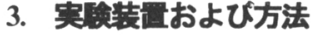

実験装置と計測機器の概略を図 1 に示す。風洞 の全長は $6000 \mathrm{~mm}$ で, 軸流送風機は $55 \mathrm{~kW}$ の三相 誘導電動機駆動である. 風洞の吐出口には, 二種類 のノズル(No.1 ノズルと No.2 ノズル)が用いられた. No.1 ノズルは, $500 \mathrm{~mm} \times 500 \mathrm{~mm}$ で, 吐出口の最 大風速は約 $50 \mathrm{~m} / \mathrm{s}$ である。また，No.2 ノズルは， $1250 \mathrm{~mm} \times 400 \mathrm{~mm}$ で, 吐出口の最大風速は約 $40 \mathrm{~m} / \mathrm{s}$ である. 流速分布はともに最大で士7\%以内， 乱れ強さは $0.5 \%$ 以内である. 風洞実験では, 風速 を低流速から段階的に増加させ, 風速増加に伴うか わらの挙動を測定した. 模型屋根上に敷かれた 25 枚のかわらは, 風洞吐出口の下流に 5 行 $\times 5$ 列で配 置し, 図 1 に示す吐出口から最も上流のかわらま での距離は $265 \mathrm{~mm}$ であり，実験内容によってある 程度変化させた. かわらはシール材によって屋根地 との隙間が密封されている. かわら 1 枚の重量は 約 $2.8 \mathrm{~kg}$ である. かわらの振動計測は, 加速度セン サ(ONO SOKKI NP3560, $X, Y, Z$ 三軸同時測定 可能, $10 \mathrm{~mm}$ 角, 重量 $5 \mathrm{~g}$ ), FFT アナライザ(ONO SOKKI DS-0264, 入力チャンネル数 4), およびレ 一ザドップラ振動計(OMETRON VS 1000, レーザ 出力 $0.95 \mathrm{~mW}$ )により実施した. また, 別途, かわ らの固有振動数をハンマリング試験によって計測し た。 ハンマリング試験はかわらを宙吊りにした状態 とクッション材の上にかわらを設置した場合につい て固有振動数を計測した. かわらが振動し飛散に至 るまでの過程は, 高速度ビデオカメラ(PHOTRON, 最高フレームレート $2000 \mathrm{fps}$ )により撮影された。一 方, 風による模型屋根裏面の内部圧力の変化をモ二 夕するために, 小型圧力変換器 (COPAL ELECTRONICS PA-850, 定格圧力 $100 \mathrm{kPa}$ )を屋根

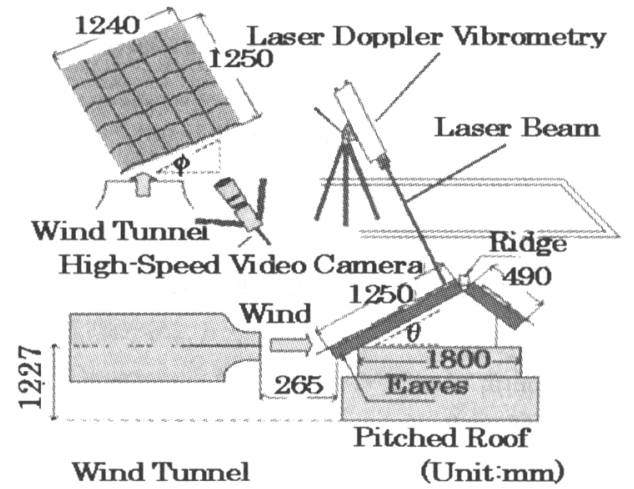

Fig.1 Experimental apparatus
裏面に取り付けた。かわら近傍の流れの測定には熱 線流速計を使用した。加速度センサの写真を図 2 に，取り付け方法を図 3 にそれぞれ示す。かわら 中央部の裏面に穴加工を施し，金属板とボルトによ って固定した。 $X, Y, Z$ の三軸方向の振動を解析 するために FFT アナライザにより周波数の解析を 行った. その際, 加速度センサは金属板によって固 定されているため, かわら裏面との接触共振の可能 性が眯念される、レーザドップラ振動計による計測 では，模型屋根上方 $1500 \mathrm{~mm}$ に設置されたレーザ によりかわら表面のほぼ中央を照射した。レーザド ップラ振動計の測定精度を上げるために，対象物へ の照射レーザの反射強度が最大となるように光学系 を調整した．高速度ビデオカメラ撮影では，飛散に 至るかわらの挙動を画像により記録した. 小型圧力 変換器は, 模型屋根裏面に穴加工を施し取り付けた。 また，熱線流速計のプローブによりかわら近傍の流 れを計測し，信号を FFT アナライザ八入力して乱 れの解析を行った。

\section{4. 実驗吉果および考宾}

\section{$4 \cdot 1$ かわらの振動解析 かわらの振動解析で} は, 屋根勾配 $\theta$ を $0^{\circ} \sim 30^{\circ}$ に設定し, 風向角 $\phi$ を $0^{\circ} \sim 45^{\circ}$ に変化させた。 また, FFT アナライザの サンプリング周波数を 2048 点に設定し, 分解能点 数は 800 ライン，周波数レンジは $2,500 \mathrm{~Hz}$ に設定 した。平均化処理した振動波形を, 風速を変化させ てパソコンに記録し解析した。飛散直前のかわらの 周波数解析結果を図 4(b)に示寸. 図 4(a)は低流速に

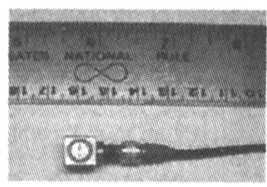

Fig.2 Acoelerometer

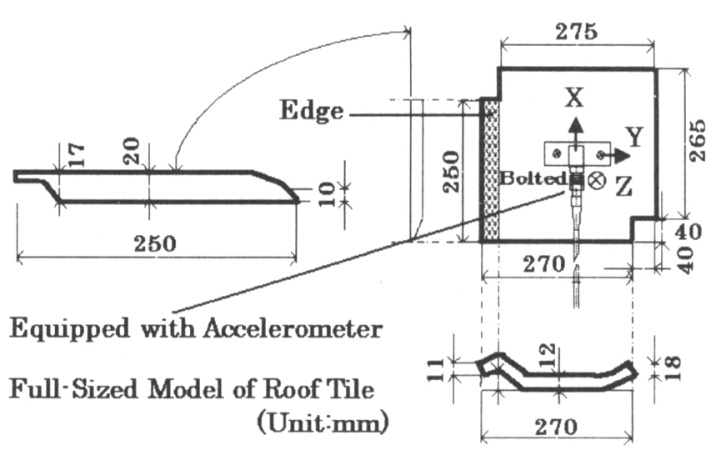

Fig.3 Roof tile equipped with accelerometer 


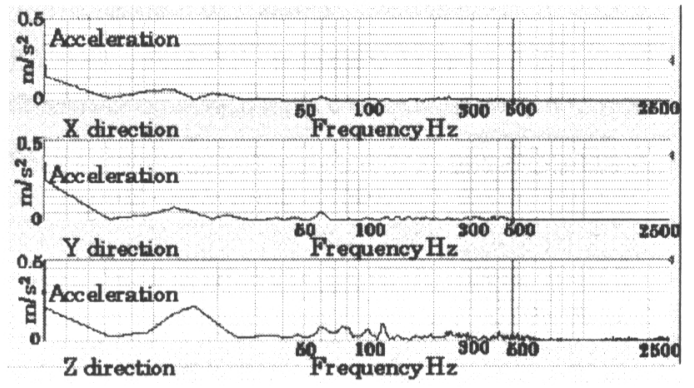

(a) Resultsin $U=20.0 \mathrm{~m} / \mathrm{s}$
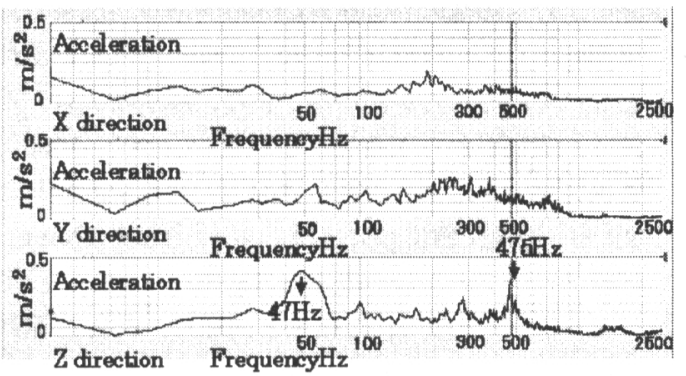

(b) Resultsin $U=49.0 \mathrm{~m} / \mathrm{s}$

Fig4 Vibraional acoderation powerspectum for tileat $\theta=29^{\circ}, \phi=0$

おける U $20.0 \mathrm{~m} / \mathrm{s}$ での解析結果の一例であるが, 低流速においては, 顕著な振動スペクトルの発生は 確認されない. しかし, 飛散直前の $U=49.0 \mathrm{~m} / \mathrm{s}$ に おける図 4(b)では, 振動スペクトルのピークが顕著 に現れている．特に両者を比較した場合，かわらが 飛散する直前の $U=49.0 \mathrm{~m} / \mathrm{s}$ では $Z$ 軸方向, すなわ ちかわら表面に垂直な方向の振動が現れ， $475 \mathrm{~Hz}$ の明瞭な振動スペクトルのピークを記録した。その 他の周波数としては， $Z$ 軸方向で $47 \mathrm{~Hz}$ が出現した。 なお， $X$ 軸(かわら表面に沿う主流方向)と $Y$ 軸(かわ ら表面に沿う主流に直角方向)に関しては， $Z$ 軸方 向に現れたような卓越した周波数のピークは出現し なかった。一方, 振動振幅の計測に関しては, 変位 を時間で 2 回微分すれば加速度が得られる。なお, 周波数が比較的高い場合には変位を計測するより加 速度で測定した方が，一般的には感度よく測れるこ とが知られている. 本実験では加速度計で振動振幅 を計測しており，振動振幅の大きさが周波数スペク トルのピークの高さに対応している. 以上の解析結 果から，かわらの表面に垂直な方向の振動が顕著に 現れ，風速が増加するにつれて振動の振幅も増加す る傾向が見られた。

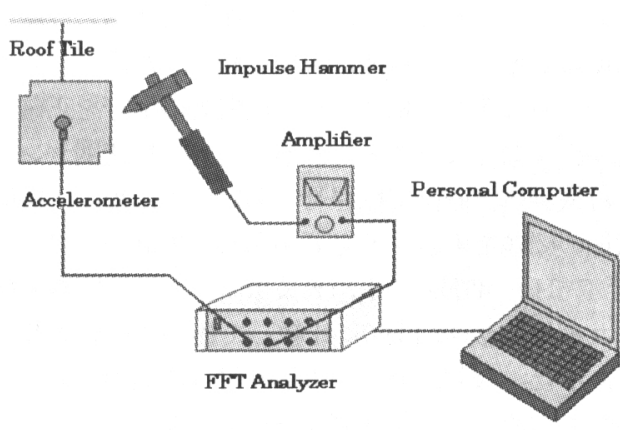

Fig5 Impulseformehammertest forroof tile

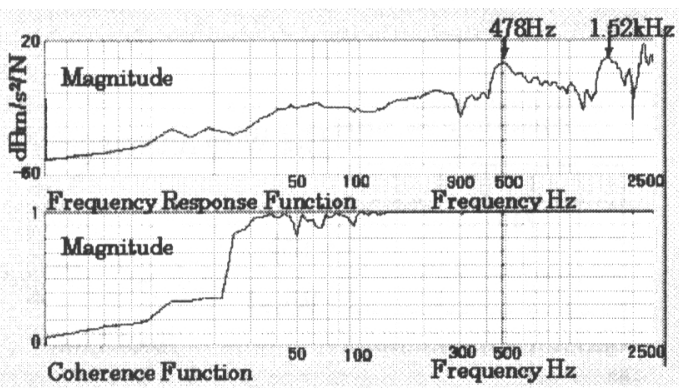

Fig.6 Frequency response function and ooherence function for tiles by impulse hammer test under no flow condition

かわらの固有振動数を求めるため, ハンマリング 試験を行った．かわらを吊るした状態とクッション 材の上に置いた状態の測定結果は, 固有振動数がと もに一致し, 両者の差異は認められなかった. 吊る した状態の実験方法の概略を図 5 に示す。宙吊り に設置したかわらの中央部にインパルスハンマに打 撃を加える. 固有振動数の解析には, 周波数応答関 数とコヒレンス関数(4) を求めた. 八ンマリング試 験結果の一例を図 6 に示す. 周波数応答関数では $478 \mathrm{~Hz}$ の周波数でピークが出現し, その他, $1.52 \mathrm{kHz}$ の周波数の発生も測定された. その時のコ ヒレンス関数には高い相関が見られた. 図 4(b)で示 された飛散直前に発生する卓越周波数とハンマリン グ試験により得られたかわらの固有振動数とは, ほ ぼ一致することがわかった。

本実験で得られた加速度センサによる振動解析の 結果を検証するために，レーザドップラ振動計によ り周波数計測を実施した。 その結果, 測定䛊差の範 冊内では有意差は見られなかった。レーザドップラ 振動計による計測のメリットは, 非接触の計測が可 能であること, ならびに加速度センサ自身による付 加的な質量の影響を除去出来ることである．また， 
デメリットとしては，かわらが振動を開始し，徐々 に振幅が増大して口開け現象を起こすために, レー ザの照射位置が大幅にずれ，反射光の信号を正確に 受光出来なくなることである．一方，加速度センサ では振動体に直接接触させて測定するために，接触 共振の問題を考虑する必要がある. 本計測で得られ た $475 \mathrm{~Hz}, 47 \mathrm{~Hz}$ の卓越周波数は，センサ固有の接 触共振周波数(数 $\mathrm{kHz}$ )に比較して極めて低い周波数 であった. なお，センサの取り付け器具の共振の可 能性も含めて, 今後詳細な検討が必要である.

$4 \cdot 2$ かわら近傍の流れ かわら近傍の流れ, とりわけ，かわらのエッジの影響を調べるために， 真横からの風，すなわち風向角が $90^{\circ}$ で模型屋根

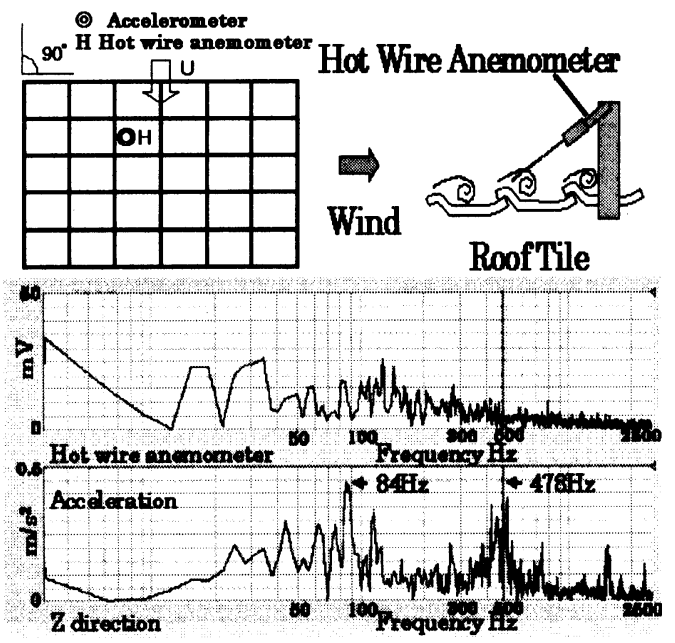

Fig.7 Vibrational acceleration and turbulence power spectrum for roof tiles at $\theta=0^{\circ}, \phi=90^{\circ}$ and $U=40.0 \mathrm{~m} / \mathrm{s}$
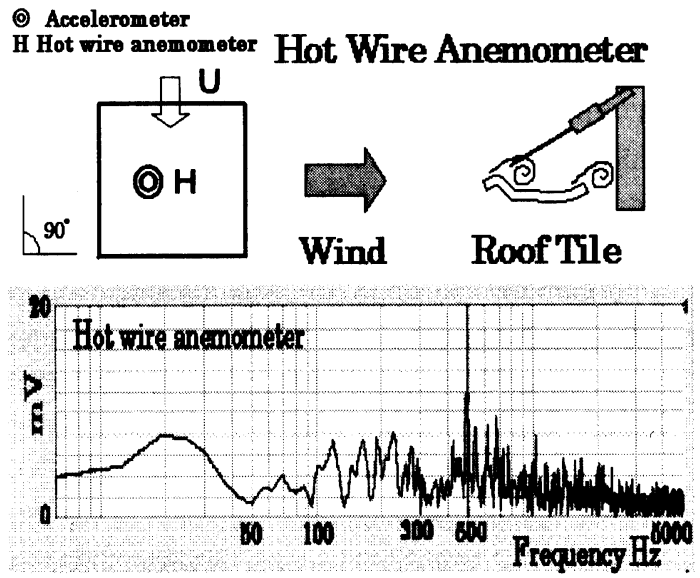

Fig.8 Turbulence power spectrum for a roof tileat $\theta=0^{\circ}, \phi=90^{\circ}$ and $U=40.0 \mathrm{~m} / \mathrm{s}$
勾配を $0^{\circ}$ に設定した．本実験に限り風洞吐出口の 下流には 5 行 $\times 6$ 列で実物かわらを配置した. 加速 度センサと熱線プローブの測定位置，ならびに計測 の結果を図 7 に示す．また，かわら表面から熱線 プローブ先端までの距離は $2 \mathrm{~mm}$ から $20 \mathrm{~mm}$ の範 囲で距離を変化させて計測を行った。低流速の流九 では, 加速度センサの振動波形と熱線流速計の出力 波形は共に微弱である．風速が増加するにしたがい 加速度センサには顕著なピーク周波数が発生するが (図 4(b)), 熱線流速計の周波数スペクトルには特定 のピーク周波数は認められず，低周波域から高周波 域にかけて多数のランダムなスペクトルが出現し， 風洞吐出口の一様流れと比較して極めて乱れた流れ となっていることがわかる. また, 風洞吐出口の下 流に，実物かわら 1 枚を別途設置し $\left(\theta=0^{\circ}, \phi=90^{\circ}\right)$, 熱線プローブによりかわら表面上の流れを計測した (図 8). 計測位置については, エッジ後方 $40 \mathrm{~mm}$, 熱線プローブとかわら表面との距離は $2 \mathrm{~mm}$ に設定 した. 図 7 で得られた結果と同様に, 熱線流速計 の周波数スペクトルには特定のピーク周波数の発生 は認められず，低周波域から高周波域にかけて多数 のスペクトルが発生し, 風洞吐出口の一様流れと比 較して極めて乱れた流れとなっていることがわかっ た.

加速度センサの測定結果から，風速変動の作用に よってかわらが強制振動現象(バフェティング)を起 こし, 風速と乱れの強さに依存して顕著なピーク周 波数となって現れた. 一方, 風の流れによりかわら から渦が流出している.この渦流出の周波数は風速 に比例する形で表され，理論上は断面形状のストロ 一ハル数で表現される. 一方，かわらの振動之渦の 関係は，かわらが流れの中に置かれた時，かわらの 振動の固有周波数と渦発生の周波数が一致すると共 振を起こし，さらに大きな振動を引き起こすと予測 される. しかし，実験で使用した実物かわらはエッ ジ部分において湾曲した独特の形状と鈍頭の断面を 有しているために，流れがエッジ表面で剥離すると 考えられる. エッジを含むかわら形状全体から考察 すれば，エッジ表面で剥がれた流れがかわらに再び ぶつかる再付着型の流れが形成されていると考えら れる. 再付着型の流れでは, 再付着する流れに物体 （かわら）の影響，特に振動している場合にはかわら の運動の影響が顕著に現れる. 流れが物体に再付着 する現象は振動によって促進されたり，また，崩壊 して下流に流出するために，エッジ部分やかわら表 面上には複雑な流れの場が形成されていると考えら 


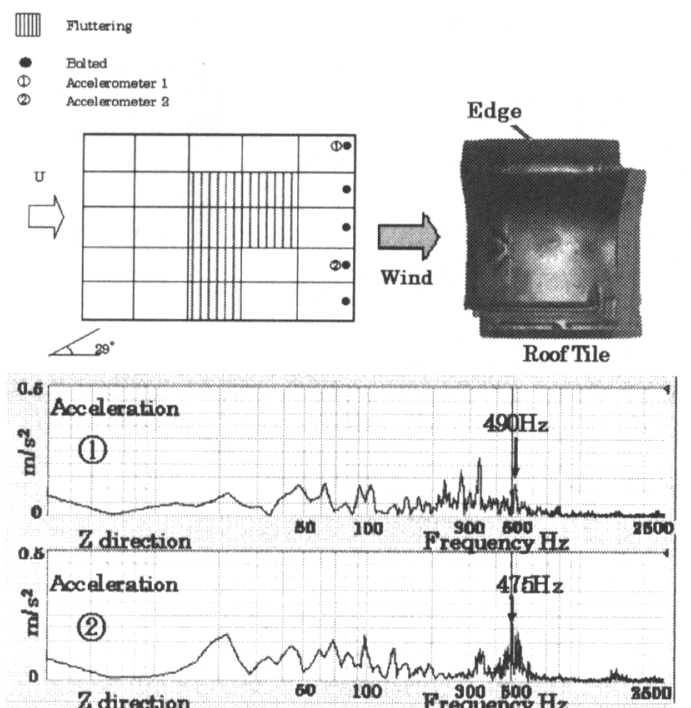

Fig.9 Vibrational acceleration power spectrum for roof tiles at $\theta=29^{\circ}, \phi=0^{\circ}$ and $U=39.0 \mathrm{~m} / \mathrm{s}$
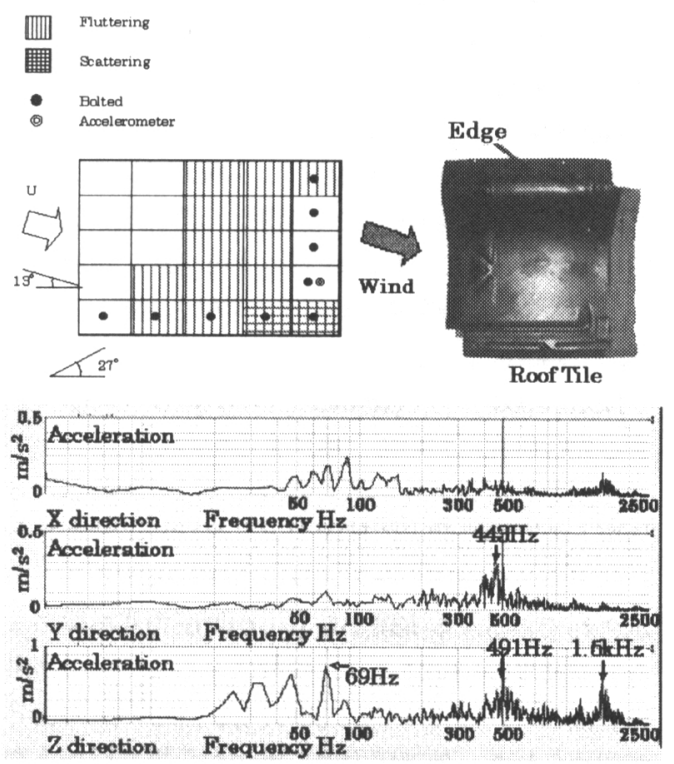

Fig.10 Vibrational acceleration power spectrum for roof tiles at $\theta=27^{\circ}, \phi=13^{\circ}$ and $U=40.0 \mathrm{~m} / \mathrm{s}$

れる. かわら表面上やエッジで生じる流れの詳細な 様相と加速度センサより得られた卓越周波数との関 連に関しては，今後より精密な解析を行う予定であ る.

\section{$4 \cdot 3$ かわらの振動と飛散の挙動 一連の風洞実} 験では，模型屋根の勾配を 00 から $30^{\circ} に$ にまた，風 洞吐出口からの風向角を $0^{\circ}$ から $45^{\circ}$ まで変化させ

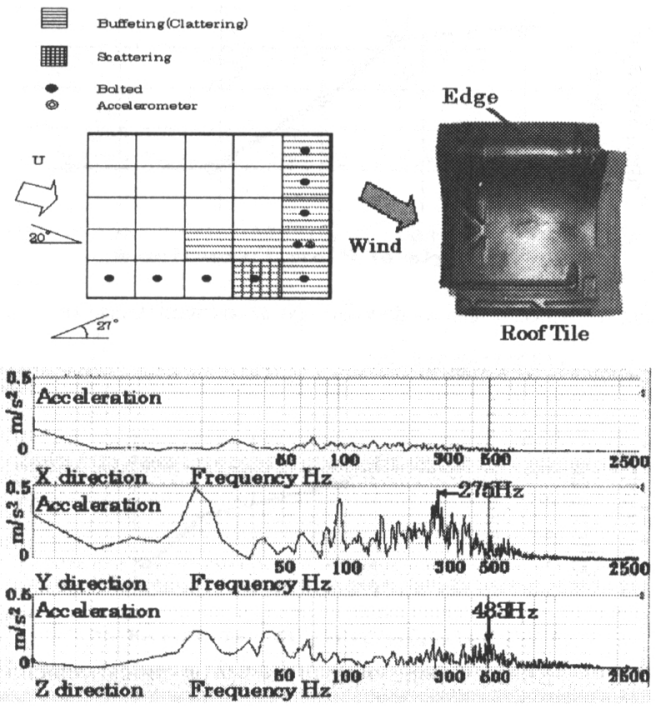

Fig.11 Vibrational acoeleration power spectrum for roof tiles at $\theta=27^{\circ}, \phi=20^{\circ}$ and $U=35.0 \mathrm{~m} / \mathrm{s}$

て実験を行った。図 9 には, 異なる 2 箇所の位置に 設置されたかわらの振動周波数を各々の加速度センサ (図中の(1)と(2))で同時に測定した結果の一例を示寸。 屋根下流の 5 枚のかわらにはビス止加工を施し，ビ ス止めの有無による耐風性の確認を別途行った. 1 本 のビス止めのみでは，かわら自体に多少のガタがある ために不安定で, 風速の増加によって振動が発生する. 実験では風速が $39.0 \mathrm{~m} / \mathrm{s}$ の時, かわらの先端部が上下 に大きく振動する口開け現象(フラッタリング)が発生 した(図 9 上図の縦縞). また, 2 個の加速度センサで は $490 \mathrm{~Hz}$ と $475 \mathrm{~Hz}$ の周波数の発生が確認できた(図 9 下図).

風向角を変化させた場合の実験結果の一例を図 10 と図 11 にそれぞれ示寸。この時の屋根勾配は共に $27^{\circ}$ に設定した. ここでは, 合計 9 枚のかわらにビス 止め加工を施した，図 10 には，風向角を 13 に設定 した時の結果を示す. 最初微小な振動が発生し, 口開 け現象を起した後に, $40.0 \mathrm{~m} / \mathrm{s}$ で 2 枚のかわらが飛散 した(図 10 上図の格子模様)。振動のパワースペクトル では, $Z$ 軸方向では $491 \mathrm{~Hz}$ のピーク周波数の他に $69 \mathrm{~Hz}, 1.5 \mathrm{kHz}$ の振動周波数が認められ， $Y$ 軸方向 では $443 \mathrm{~Hz}$ の振動周波数が見られた. 図 11 には, 風向角が $20^{\circ}$ におけるかわらの挙動を示寸，局所 的に見た場合，着目している特定のかわらは，その 前列および両隣りのかわらから発生した渦や乱れの 影響を受けて，かわら表面近傍の流れは極めて変動 した流れになっていることが熱線流速計の計測から 


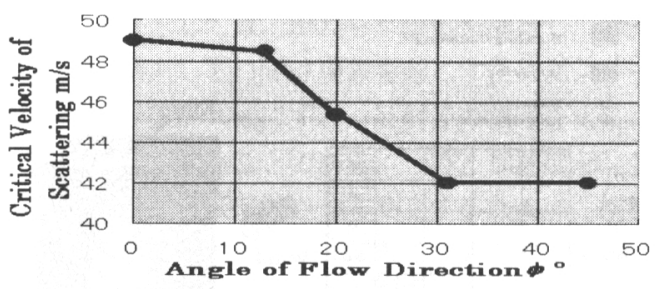

Fig.12 Effect of angle of flow direction $\phi$ on critical velocity of scattering for roof tiles

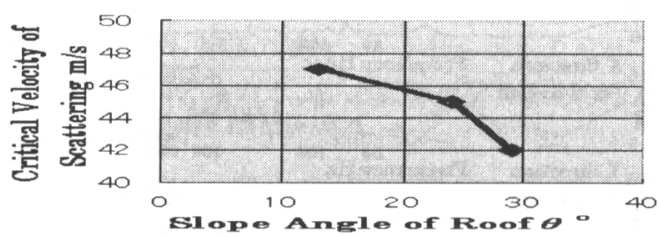

Fig.13 Effect of slope angle of roof $\theta$ on critical velocity of scatteringfor roof tiles

わかっている，模型屋根上に敷かれたかわらは，最 初ずれが生じ，次いで風速変動による微小な振動現 象(バフェティング)が認められ，その後，フラッタ リングを起こして，風速が $35.0 \mathrm{~m} / \mathrm{s}$ で飛散した。 ま た，振動周波数は， $Z$ 軸方向においては $483 \mathrm{~Hz}$ の ピーク周波数， $Y$ 軸方向でも $275 \mathrm{~Hz}$ のピーク周波 数が見られた。風向角の影響としては， $13^{\circ}$ の時 $40.0 \mathrm{~m} / \mathrm{s}$ で飛散し(図 10), 風向角を $20^{\circ}$ に増加した 時には, より低流速の $35.0 \mathrm{~m} / \mathrm{s}$ で飛散した(図 11). また，これらの実験結果より振動や飛散を引き起こ し易いかわらは，屋根下流の右端に局部的に集中して いることがわかった．ビス止めの効果については，特 に振動や飛散に弱いと考えられる屋根下流の右端のか わらに施工寸ることが有効であると考えられる。この 理由として, かわら形状の左右の非対称性, および模 型屋根上におけるかわらの蕞き方に起因することが考 えられる，すなわち，風向角を $20^{\circ}$ に傾けた場合に は, 隣接する上下, 左右のかわ的らとの重なり具合によ り，風がかわらとかわらの陌間から屋根内部に侵入す る. その結果, 屋根裏面と野地板との間の空間の内部 圧力を上昇させてかわらを押し上げる力として働くた めに，かわらが飛散しや寸挎ると考えられる。逆に， 風向角がー200 の場合には，かわらの重なり具合によ り，隙間が流れに面してはいないために，上記のよう な現象は避けることが出来る.

図 12 には，かわらが飛散し始める流速におよぼす 風向角の影響を示寸，風向角が増すにつれ，振動や飛 散を引き起こし易くなり，飛散に至る風速も低下寸る
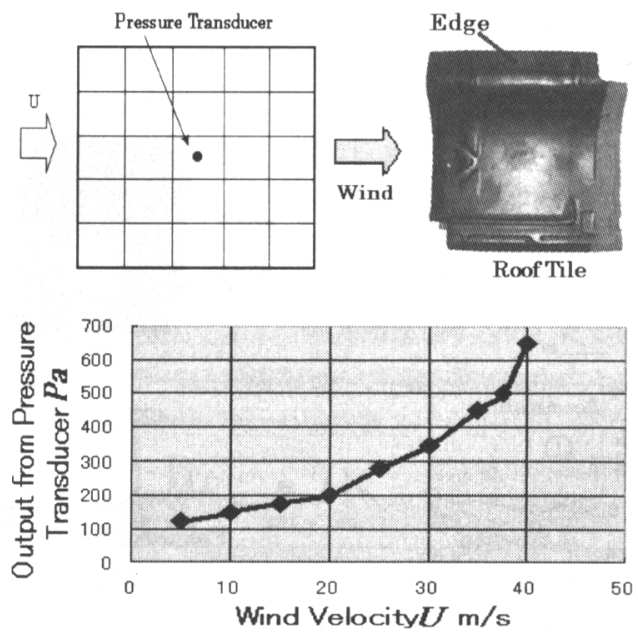

Fig.14 Measurement by the pressure transducer and its position at $\theta=29^{\circ}$ and $\phi=0$

傾向が見られた，一方，図 13 には，風向角が 00 の 場合に，かわらの飛散流速におよぼす屋根勾配の影響 を示寸，屋根勾配が $\theta=13^{\circ}$ の時は飛散に至る限界流 速は $U=47.0 \mathrm{~m} / \mathrm{s}$ で, 勾配が増加した $\theta=29^{\circ}$ の時は $U=42.0 \mathrm{~m} / \mathrm{s}$ であった. 寸なわち, 緩やかな勾配ではか わらは振動や飛散に比較的強く，勾配が急になるにつ れ振動の発生が早まり, その結果, 限界流速が低下し て，飛散し易いこともわかった，屋根勾配の影響につ いては, 今後, 棟を越える気流の挙動も考慮して, 包 括的に議論していく必要がある.

Hazelwood ${ }^{(5)}$ や Kramer ${ }^{(6)}$ のかわらの飛散に関 する先行研究において，風によるかわらの浮き上が りと飛散に至るメカニズムについては，かわらと野 地板との間の空間の内部圧力と，流れによりかわら に作用する外部圧力とのバランスに起因することが 示されている. 本実験からも，小型圧力変換器によ る計測結果(図 14)により, 飛散に至るまでの模型屋 根裏面(かわらと野地板の間の内部空間)の圧力上昇 が認められた。外部圧力は, 風洞から模型屋根上を 流れる風により発生するが，屋根に葺いたかわらの 隙間等から浸入する流れによる内部圧力の上昇によ り，かわらを浮き上がらせ，さらにこのかわらが外 部を流れる風により飛ばされる，高速度ビデオカメ ラ撮影の連続写真を図 15 に示寸。図 15 では，か わらが振動を開始し(写真 1), やがて写真 2 から大 きな口開け現象を起こしてフラッタリングが生じ (写真 9 まで), 写真 10 から 16 にかけて最終的に飛 散に至る一連の詳細なメカニズムが明らかとなった。 


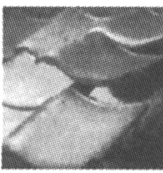

1

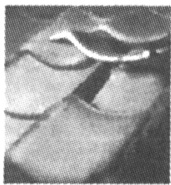

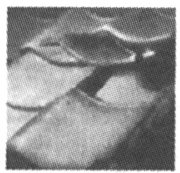

2

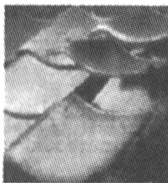

10

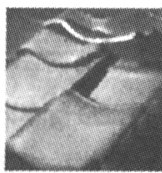

3

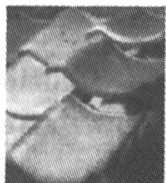

11

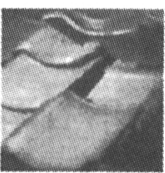

4

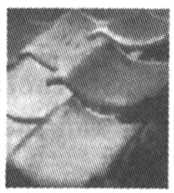

12

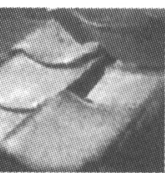

5

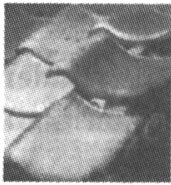

13

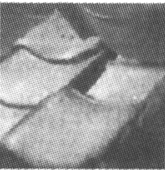

6

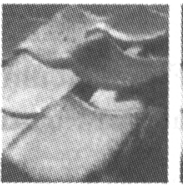

14

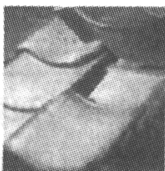

7

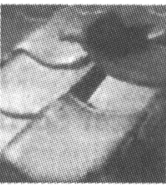

15
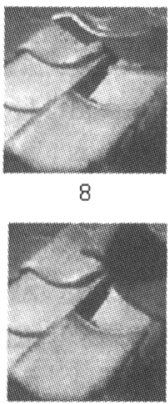

16

Fig.15 Lifting up of roof tiles due to wind action by hight-speed video camera at $\theta=29^{\circ}, \phi=0^{\circ}$ and $U=42.0 \mathrm{~m} / \mathrm{s}$. Images are acquired at 2,000frames per second.

\section{5. 結}

本研究では，従来ほとんど注目されていなからたか わらの飛散の前兆現象である動摇(がたつき，ずれ)に 着目し，風洞実験によりそれらのメカニズムを解析し た.この結果，以下のことがわかった.

（1）飛散直前のかわらの振動周波数は，ハンマリ ング試験で得られた固有振動数とほぼ一致した。

（2）風向角の影響については, 風向角が増すにつ れ，振動や飛散を引き起こし易くなり，飛散に至る 風速も低下寸る傾向が見られた。 また，振動や飛散 を引き起こし易いかわらは局所的に限定され，屋根 下流の右端に集中していることがわかった.

（3）屋根の傾斜を変化させた場合，緩やかな勾配 では振動や飛散に強く，勾配が急になるにつれて， 振動の発生が早まり，その結果，飛散し易いことが わかった。

\section{文南}

（1）岡田恒，強風による屋根瓦の飛散に関する風洞実験，日本 風工学会誌，35(1988-4)，1-15

（2）赤崎褆璋・斉藤通・本田明弘・佐藤勝彦，屋根瓦に作用寸 る風力に関する研究，日本風工学会誌，58 (1994-1)，19-31

（3）河井宏允・西村宏昭, 自然風中にある屋根瓦に作用する風 力，京都大学防災研究所年報， 45B-1(2002-4).

（4）城戸健一，2 チャンネル FFTアナライザ活用マニュアル， (1985)，1-99，日本プラントメンテナンス協会

(5) Hazelwood, R.A, Principles of wind loading on tiled roofs and their application in the British standard BS5534, J. Wind Engineering and Industrial Aerodynamics, 6(1980), $113-124$

(6) Kramer, C. and Gerhardt, H. J. , Wind loads on permeable roofing systems, J. Wind Engineering and Industrial Aerodynamics, 13(1983), 347-358. 